\title{
Erratum to: RUNX1 induces DNA replication independent active DNA demethylation at SPI1 regulatory regions
}

Shubham Goyal, Takahiro Suzuki, Jing-Ru Li, Shiori Maeda, Mami Kishima, Hajime Nishimura, Yuri Shimizu and Harukazu Suzuki*

\section{Erratum to: BMC Molecular Biol (2017) 18:9 \\ DOI 10.1186/s12867-017-0087-y}

The original article [1] contained an error in the title whereby the word 'of' was mistakenly inserted between 'independent' and 'active' during the article's production.

As such, the original article title has now been updated to reflect the correct title.

The online version of the original article can be found under doi:10.1186/s12867-017-0087-y.

\section{Publisher's Note}

Springer Nature remains neutral with regard to jurisdictional claims in pub-

lished maps and institutional affiliations.

Received: 13 April 2017 Accepted: 13 April 2017

Published online: 21 April 2017

\section{Reference}

1. Goyal S, Suzuki T, Li J-R, Maeda S, Kishima M, Nishimura H, ShimizuY

Suzuki H RUNX1 induces DNA replication independent active DNA demethylation at SPI1 regulatory regions. BMC Mol Biol. 2017;18:9. doi:10.1186/s12867-017-0087-y.

\section{*Correspondence: harukazu.suzuki@riken.jp}

Division of Genomic Technologies, RIKEN Center for Life Science

Technologies, 1-7-22 Suehiro-cho, Tsurumi-ku, Yokohama, Kanagawa

230-0045, Japan 